\title{
Rhodopsin-induced experimental autoimmune uveoretinitis in monkeys
}

\author{
J J SCHALKEN,' H J WINKENS,' A H M VAN VUGT,' W J DE GRIP,? \\ AND $R$ M BROEKHUYSE'
}

From the 'Institute of Ophthalmology and the ${ }^{2}$ Department of Biochemistry, University of Nijmegen, $6500 \mathrm{HB}$ Nijmegen, The Netherlands

SUMMARY We present the first evidence that purified rhodopsin can induce experimental autoimmune uveoretinitis (EAU) in monkeys. Injection of a highly purified lipid-free rhodopsin preparation provokes severe chorioretinitis with concomitant anterior uveitis. The onset of disease is earlier, its frequency is higher, and the inflammation is considerably more severe than in EAU induced under similar conditions by opsin. The first inflammatory cells are observed in the ciliary body and pars plana. Within a few days the inflammation extends into the anterior chamber, choroid, and retina. Retinitis predominates in the central area, while chorioretinitis is observed in the periphery, both accompanied by damage to and elimination of the photoreceptor cells. The monkeys develop high cellular and humoral immune responses against rhodopsin and opsin. The cellular response maximum just precedes the onset of EAU. This may indicate that cellular immunity has an important role in the pathogenesis of rhodopsin-induced EAU.

Autoimmune reactions against retina-specific proteins are suspected of playing an important part in the pathogenesis of uveitis. Uveitis-like disease can be experimentally induced in animals such as the rat and guinea-pig by injection of these proteins. ${ }^{1-10}$ As such the model of experimental autoimmune uveoretinitis (EAU) is useful in studies of the pathogenesis of uveoretinal disorders as well as of the role of autoimmune reactions in these processes. As a model for human disease, primates are of particular interest in this kind of studies. In purified form, S-antigen, ${ }^{11}{ }^{12}$ opsin,${ }^{13}$ and IRBP (interphotoreceptor retinoid-binding protein $)^{14}$ is have been reported to induce uveoretinitis in monkeys.

Recently we have presented evidence that in Lewis rats rhodopsin is considerably more pathogenic than opsin. ${ }^{8}$ Here we present the first report on the induction of uveoretinitis in monkeys by pure rhodopsin. The clinical state, histological changes, and cellular and humoral immune responses of the injected animals have been evaluated.

\section{Materials and methods}

PREPARATION OF ANTIGENS

For the induction of EAU highly purified lipid-free

Correspondence to Dr R M Broekhuyse. rhodopsin was prepared as described previously. ${ }^{816} \mathrm{~A}$ reconstituted rhodopsin preparation was used as test antigen. ${ }^{8}$ All procedures involving rhodopsin were performed under dim red light $(\lambda>620 \mathrm{~nm})$. In order to prepare opsin, a rhodopsin preparation was illuminated just before use by means of a $100 \mathrm{~W}$ tungsten lamp at $30 \mathrm{~cm}$ distance for 10 minutes at room temperature. Bovine S-antigen and IRBP were prepared as described previously. ${ }^{1017}$

IMMUNISATION, CLINICAL OBSERVATION, AND HISTOLOGICAL EVALUATION

Four young adult female stump-tailed macaques (Macaca artoides) were each injected with $650 \mu \mathrm{g}$ rhodopsin under dim red light. About $400 \mu \mathrm{g}$ of antigen was emulsified in Freund's complete adjuvant (Difco, Detroit) and injected subcutaneously at 10 sites interscapularly. The rest of the antigen was injected intraperitoneally in $1 \mathrm{ml}$ pertussis vaccine (Haemophilus pertussis; $5 \times 10^{9}$ micro-organisms, $1.25 \mathrm{mg}$ aluminium hydroxide, Pasteur Institute, Paris). The animals were housed under darkroom conditions for the first 10 days after injection and subsequently housed under normal diurnal light-dark conditions (12h light : $12 \mathrm{~h}$ dark). Under these conditions the subcutaneously injected rhodopsin was protected against light effects during the critical 168 
ments with rats showed that housing in darkness for a period of eight days is sufficient to achieve this goal. Housing in darkness itself has no detectable influence on the development of rhodopsin-induced EAU. ${ }^{818}$ From day 10 after injection the clinical signs of uveitis were monitored by slit-lamp examination. Occasionally the fundi were examined by indirect ophthalmoscopy.

For histological examination animals were killed at various stages of the disease (Table 1). The eyes were fixed in Bouin fluid, embedded in paraffin, and $5 \mu \mathrm{m}$ sections were stained with haematoxylin and eosin.

\section{IMMUNE RESPONSES}

The humoral and cellular immune responses were determined weekly using enzyme-linked immunosorbent assay (ELISA) and lymphocyte transformation test (LTT), respectively. In the latter assay, rhodopsin, opsin; and S-antigen were applied as test antigens. In the ELISA, IRBP was used as an additional test antigen. Optimal antigen concentrations were determined in previous experiments.

The ELISA was carried out essentially as described before ${ }^{8}$ with a reconstituted rod outer segment membrane preparation containing 5 pmol rhodopsin (based on absorbance spectroscopy) per ml buffered saline ( $0.02 \mathrm{M}$ phosphate, $\mathrm{pH} 7 \cdot 6)$ to coat the wells.

Cellular immune responses were determined by means of lymphocytes separated from heparinised blood by lymphocyte separation medium (Boehringer, Mannheim). The lymphocyte transformation test was carried out as described previously ${ }^{6}$ with $10 \%$ heat-inactivated monkey serum in the culture medium and $5 \mu \mathrm{g}$ test antigen per ml cell suspension. All samples were manipulated under dark room conditions until the cells were harvested.
Table 1 Clinical features of rhodopsin-induced uveoretinitis in monkeys

\begin{tabular}{|c|c|c|c|c|c|c|}
\hline \multirow{3}{*}{$\begin{array}{l}\text { Monkey } \\
\text { no. }\end{array}$} & \multirow{3}{*}{$\begin{array}{l}\text { Day of } \\
\text { onset }\end{array}$} & \multirow{3}{*}{$\begin{array}{l}\text { Day of } \\
\text { listed } \\
\text { scores }\end{array}$} & \multicolumn{4}{|c|}{ Slit-lamp score* } \\
\hline & & & \multicolumn{2}{|c|}{ Left eyet } & \multicolumn{2}{|c|}{ Right eyet } \\
\hline & & & $A C$ & $V I T$ & $A C$ & $V I T$ \\
\hline L64 & 21 & 21 & 0 & 0 & $2+$ & $2+$ \\
\hline L70 & 23 & 24 & $2+/ 3+$ & $3+$ & $1+$ & $2+$ \\
\hline L76 & 24 & 31 & $4+$ & NV & $2+$ & $2+$ \\
\hline \multirow[t]{5}{*}{$\mathrm{L} 77$} & 24 & 24 & 0 & $1+$ & 0 & 0 \\
\hline & & 41 & $2+$ & $2+$ & $3+$ & $4+$ \\
\hline & & 48 & $3+$ & $2+$ & $3+$ & $2+$ \\
\hline & & 55 & $1+$ & $1+$ & $2+$ & $1+$ \\
\hline & & 70 & 0 & $1+$ & 0 & $1+$ \\
\hline
\end{tabular}

*Score on the day the animal was killed (L64, L70, L76) and in addition for $\mathrm{L} 77$ also at other days when the eyes showed typical characteristics of inflammation as listed. Scores: $1+$, a few cells in aqueous and/or vitreous; $2+$, cells in the aqueous and moderately dense cell infiltration of the vitreous: $3+$, cells and protein in the aqueous, dense cell infiltration of the vitreous, poor fundal view; $4+$, dense cell infiltrations in the vitreous blocking the fundal view, protein precipitates and many cells in the aqueous. $\dagger \mathrm{AC}=$ anterior chamber. VIT = vitreous. $\mathrm{NV}=$ not visible.

Results were expressed as stimulation indices (SI):

$\mathrm{SI}=$ counts per minute in presence of antigen/ counts per minute in absence of antigen.

A stimulation index $>2$ was considered to be positive. ${ }^{\circ}$

\section{Results}

\section{CLINICAL EVALUATION}

Each of the four monkeys injected with rhodopsin developed clinical signs of uveitis within 21-24 days of injection (Table 1). The first clinical features were slight cell infiltrations in anterior chamber and

Table 2 Review of histopathological features of rhodopsin-induced EAU in monkeys

\begin{tabular}{|c|c|c|c|c|c|c|c|c|}
\hline \multirow{3}{*}{$\begin{array}{l}\text { Days post- } \\
\text { injection }\end{array}$} & \multirow[t]{3}{*}{$E y e^{*}$} & \multicolumn{7}{|c|}{ Severity of inflammationt } \\
\hline & & \multirow[t]{2}{*}{$A C \ddagger$} & \multirow[t]{2}{*}{$C B / P P \ddagger$} & \multicolumn{2}{|l|}{ Periphery } & \multicolumn{3}{|l|}{ Central } \\
\hline & & & & Choroid & Retina & Choroid & Retina & $O N \ddagger$ \\
\hline $\begin{array}{l}21 \\
24 \\
21 \\
24 \\
31 \\
31 \\
70 \\
70\end{array}$ & $\begin{array}{l}\text { L64 OS } \\
\text { L70 OD } \\
\text { L64 OD } \\
\text { L70 OS } \\
\text { L76 OD } \\
\text { L76 OS } \\
\text { L77 OS } \\
\text { L77 OD }\end{array}$ & $\begin{array}{l}1+ \\
1+ \\
1+/ 2+ \\
2+ \\
1+ \\
3+ \\
1+ \\
2+\end{array}$ & $\begin{array}{l}1+ \\
1+ \\
2+ \\
2+ \\
1+ \\
3+ \\
1+ \\
1+\end{array}$ & $\begin{array}{l}0 \\
0 \\
3+14+ \\
3+14+ \\
4+ \\
4+ \\
4+ \\
4+\end{array}$ & $\begin{array}{l}0 \\
0 \\
3+14+ \\
3+/ 4+ \\
4+ \\
4+ \\
1+ \\
1+\end{array}$ & $\begin{array}{l}0 \\
0 \\
0 \\
0 \\
0 \\
3+14+ \\
2+ \\
1+/ 2+\end{array}$ & $\begin{array}{l}0 \\
0 \\
0 \\
0 \\
0 \\
3+/ 4+ \\
3+14+ \\
3+14+\end{array}$ & $\begin{array}{l}0 \\
0 \\
0 \\
0 \\
0 \\
1+ \\
2+ \\
2+\end{array}$ \\
\hline
\end{tabular}

*Monkey number and scored eye are indicated. $\mathrm{OS}=$ left eye. $\mathrm{OD}=$ right eye.

†Histological scores: 0 , normal tissue: $1+$, a few inflammatory cells: $2+$, mild cell infiltration without tissue damage: $3+$ to $4+$, dense cell infiltrations with mild to severe tissue damage.

$\ddagger A C=$ anterior chamber. $\mathrm{CB}=$ ciliary body. $\mathrm{PP}=$ pars plana. $\mathrm{ON}=$ optic nerve. 
vitreous. Mild uveitis (score $1+/ 2+$ ) developed into a severe (score $3+/ 4+$ ) panuveitis within two weeks of onset (L76 and L77). The anterior chamber was seriously affected at that stage, and dense cell infiltrations combined with the Tyndall phenomenon impaired observation of the vitreous and fundus. The iris was only slightly affected, while adherence to the lens was not observed. At this stage the retinopathy consisted of an arterial and venous perivasculitis accompanied by sheathing of the retinal blood vessels and a focally oedematous retina. In addition, oedema and hyperaemia of the optic disc were observed. About six weeks after clinical onset the inflammatory cells had disappeared from the anterior segment of monkey L77, but some inflammatory cells remained in the vitreous.

\section{HISTOPATHOLOGY}

At least unilateral severe disease was found in all the animals except L64, which was killed in the early stage. In all monkeys the first signs of ocular inflammation appeared between days 21 and 24 after injection. In all cases the disease followed a similar course in the mild, early stages. The results of the histopathological examination are summarised in Table 2.

Initial stage. At the first signs of clinical onset a few mononuclear cells were present in the anterior chamber, ciliary body, and pars plana, while in the

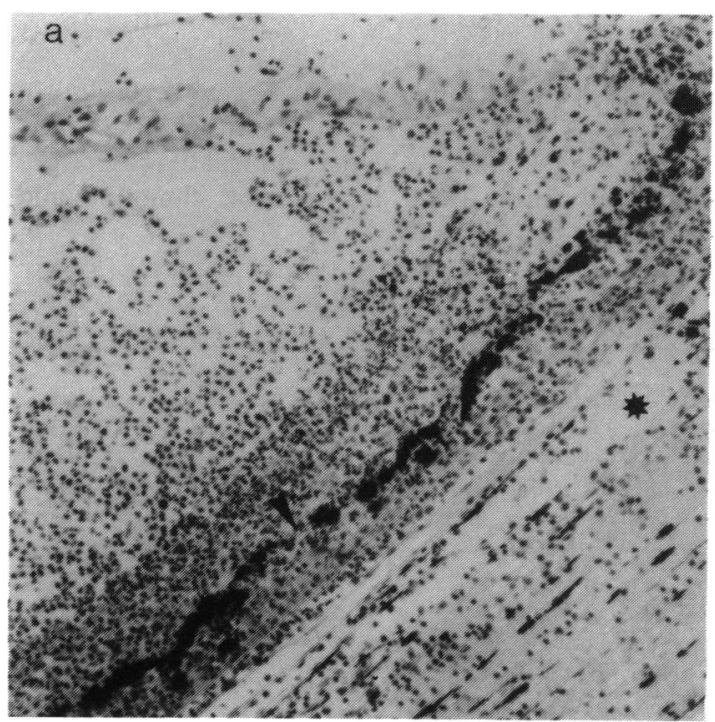

Fig. 1 Posterior segment of the monkey eye during the stage of severe inflammation. a: Peripheral chorioretinitis with many mononuclear and polymorphonuclear cells, exudate, disrupted pigment epithelium (arrow), retinal detachment, and choroidal oedema (asterisk). $\times 140$. rest of the eye no signs of inflammation were detected (L64 OS and L70 OD; Table 2).

About one day after onset (slit-lamp score $1+/ 3+$, L64 OD and L70 OS) we observed mainly focal peripheral chorioretinitis. Dense infiltrations consisting of mononuclear and many polymorphonuclear cells were locally present in choroid and retina together with perivasculitis. The anterior chamber, ciliary body, and pars plana showed a mild infiltration with mononuclear and polymorphonuclear cells, while no inflammatory cells were detectable in the iris.

Severe stage. Dense mononuclear and polymorphonuclear infiltrations were found in ciliary body, pars plana, and ora serrata. Occasionally an accumulation of mononuclear cells was observed in the region of pars plana and ciliary body. The anterior chamber and iris were seriously affected.

Severe oedema was found in the peripheral choroid, while the central part showed moderate oedema (Fig. 1a). Over the whole retina exudates and retinal detachments were observed together with local damage of the photoreceptor cells. At these sites the pigment epithelium was disrupted. The central area of the retina showed the most severe signs of inflammation consisting of mononuclear and many polymorphonuclear cells, perivasculitis, and oedematous areas in the inner and outer nuclear layers (Fig. 1b). The optic nerve head showed mild perivasculitis of the major central retinal vessels.

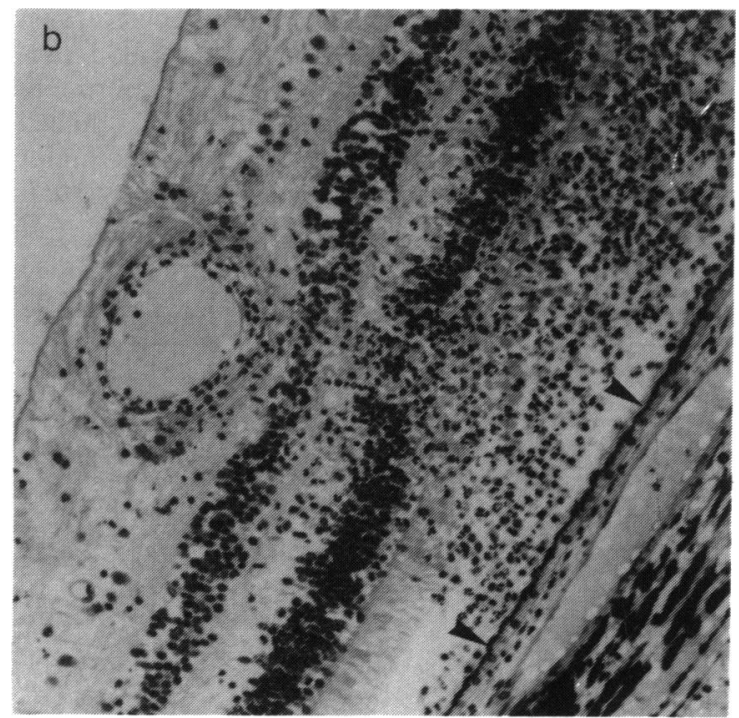

Fig. 1 b: Severe retinitis in the central part with inflammatory cells concentrated in the photoreceptor cell layer, perivasculitis, oedema of the nuclear layers, accompanied by choroiditis. The pigment epithelium is still intact (arrows). $\times 160$. 


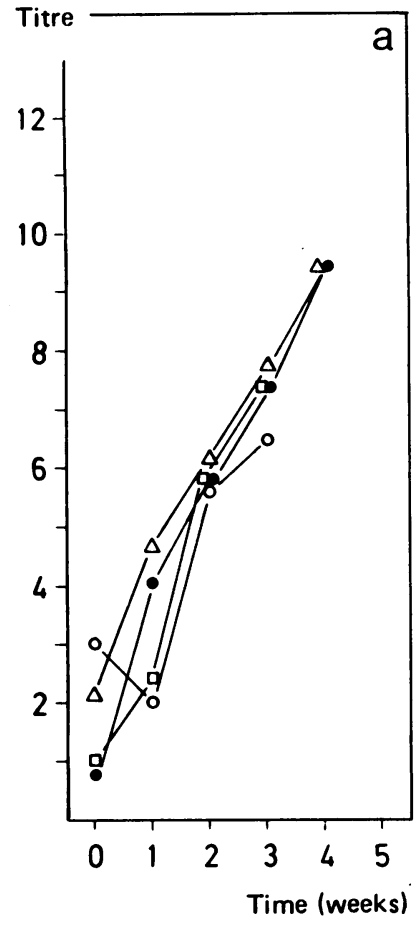

Regression stage. Seven weeks after onset of uveitis, when the disease was in the regression stage (L77, Table 1), signs of severe inflammation were still present in retina and choroid. The pigment epithelium showed extensive focal damage, with dispersion of pigment. The photoreceptor cells were severely damaged or eliminated. In general, retinitis dominated in the posterior pole of the eye, while severe chorioretinitis was observed at the periphery.

\section{IMMUNE RESPONSES}

As test antigens rhodopsin and opsin produced equal results in the immunological assays, and only the values obtained with rhodopsin are presented (Fig. 2). The time course of the development of the antibody titres showed a similar pattern for all animals (Fig. 2a). The titres continued increasing up to at least 3-4 weeks after injection. The antibody titre of monkey $\mathrm{L} 77$ reached a maximum level of about 11 in week 6 . This level was maintained for the subsequent weeks until the animal was killed (not plotted). No antibodies against S-antigen or IRBP were detectable by ELISA.

The cellular immune responses as determined by the lymphocyte transformation tests showed a different pattern (Fig. 2b). The stimulation indices also increased sharply during the first two weeks after injection but then appeared to level off (L70 and L76) or to decrease (L64 and L77). The stimulation indices determined in week 4 for the remaining two monkeys confirmed this trend. The stimulation index of monkey L77, which was measured until week 10 after injection, fluctuated during weeks 5-10 after injection round an average value of $5(\mathrm{SD} 3 ; n=5)$.

\section{Discussion}

\section{PATHOGENICITY OF RHODOPSIN}

Highly purified rhodopsin appears to be markedly pathogenic in Macaca artoides. In our laboratory an equal dose of opsin was recently shown to induce severe EAU in only two out of nine macaques with much later onset (6-10 weeks).$^{13}$ We therefore conclude that in monkeys rhodopsin is considerably more pathogenic than opsin, which agrees with results obtained recently in rats. ${ }^{81819}$

\section{CLINICOPATHOLOGICAL FEATURES OF RHODOPSIN-INDUCED EAU}

In comparison with opsin-induced uveoretinitis in the monkey, ${ }^{13}$ rhodopsin evokes a more severe chorioretinitis and an increased involvement of the anterior chamber, similar to that observed for S-antigen." 12 The histological changes share some characteristics with those described for S-antigen-induced EAU in cynomolgus monkeys, such as vasculitis and chorio- 
retinitis, which is active for a long period." This contrasts with the lack of choroidal involvement in S-antigen-induced EAU in monkeys reported by Nussenblatt et al. ${ }^{12}$

\section{IMMUNE RESPONSES}

Monkeys injected with rhodopsin showed a high cellular and humoral immune response against both rhodopsin and opsin. The humoral response appeared not to have reached its maximum level at the time of onset of disease (days 21-24 after injection). In monkey L77 the antibody titre steadily increased until five to six weeks after injection. The stimulation index, however, appeared to level off or peak just before clinical onset of disease. This may indicate that the cellular immune response has an important role in the pathogenesis of rhodopsininduced EAU in primates, as was also found in various forms of EAU in the rat. ${ }^{11}$ This is in accordance with the generally accepted idea of EAU being a model of a T-cell-mediated autoimmune disease.

We are grateful to Mrs E D Kuhlmann for her expert technical and secretarial assistance and to Dr A J J M Rademakers for funduscopy.

\section{References}

1 Wacker WB. Isolation of retinal S-antigen and its role in experimental ocular autoimmunity. In: Sears ML, ed. New directions in ophthalmic research. New Haven and London: Yale University Press, 1981: 5-29.

2 De Kozak Y, Sakai J, Thillaye B, Faure JP. S-antigen induced experimental autoimmune uveo-retinitis in rats. Curr Eye Res $1981 ; 1: 327-36$.

3 Marak GE, Rao NA. Retinal S-antigen disease in rats. Ophthalmic Res 1982; 14: 29-39.

4 Marak GE, Shichi H, Rao NA, Wacker WB. Patterns of experimental allergic uveitis induced by rhodopsin and rod outer segments. Ophthalmic Res 1980; 12: 165-76.

5 Meyers-Elliott RH, Gammon RA, Sumner HL, Shimizu I. Experimental retinal autoimmunity (ERA) in strain 13 guinea pigs. Induction of ERA-retinopathy with rhodopsin. Clin Immunol Immunopathol 1983; 27: 81-95.
6 Broekhuyse RM, Winkens HJ, Kuhlmann ED, Van Vugt AHM. Opsin-induced experimental autoimmune retinitis in rats. Curr Eye Res 1984; 3: 1405-12.

7 Broekhuyse RM, Kuhlmann ED, Van Vugt AHM, Winkens HJ. Immunological and immunopathological aspects of opsininduced uveoretinitis. Graefes Arch Clin Exp Ophthalmol 1987; 225: 45-9.

8 Schalken JJ, Van Vugt AHM, Winkens HJ, Bovee-Geurts PHM, De Grip WJ, Broekhuyse RM. Experimental autoimmune uveoretinitis in rats induced by rod visual pigment: rhodopsin is more pathogenic than opsin. Graefes Arch Clin Exp Ophthalmol 1988; 226: 255-61.

9 Gery I, Mochizuki M, Nussenblatt RB. Retinal specific antigens and immunopathogenic processes they provoke. Progr Retinal Res 1986; 5: 75-109.

10 Broekhuyse RM, Winkens HJ, Kuhlmann ED. Induction of experimental autoimmune uveoretinitis and pinealitis by IRBP. Comparison to uveoretinitis induced by S-antigen and opsin. Curr Eye Res 1986; 5: 231-40.

11 Faure JP, Le Hoang Phuc, Takano S, Sterkers M, Thillaye B, De Kozak Y. Uvéo-rétinite expérimentale induite par l'antigène $S$ rétinien chez le singe. $J$ Fr Ophtalmol 1981; 4: 465-72.

12 Nussenblatt RB, Kuwabara T, de Monasterio M, Wacker WB. S-antigen uveitis in primates. Arch Ophthalmol 1981; 99: 1090-2.

13 Broekhuyse RM, Winkens HJ, Kuhlmann ED, Van Vugt. Opsin-induced autoimmune chorioretinitis in monkeys. Proc 4th Int Symp Immunol Immunopathol Eye, Padova 1986 in press.

14 Broekhuyse RM, Winkens HJ, Kuhlmann ED. IRBP-induced autoimmune uveoretinitis and pinealitis in rats and monkeys. Proc 4th Int Symp Immunol Immunopathol Eye, Padova 1986 in press.

15 Hirose S, Kuwabara T, Nussenblatt RB, Wiggert B, Redmond TM, Gery I. Uveitis induced in primates by interphotoreceptor retinoid-binding protein. Arch Ophthalmol 1986; 104: 1698-702.

16 De Grip WJ, Daemen FJM, Bonting SL. Isolation and purification of bovine rhodopsin. Methods Enzymol 1980; 67: 301-20.

17 Broekhuyse RM, Bessems HJH. The molecular weight of bovine retinal S-antigen. Exp Eye Res 1985; 40: 763-6.

18 Broekhuyse RM, Winkens HJ, De Grip WJ. Effect of light conditions on the development of rhodopsin-induced EAU in rats. Proc 28th Meeting Ass Eye Res, Loven, 1986. Ophthalmic Res 1988; 20: 95.

19 Schalken JJ, Winkens HJ, Van Vugt AHM, Bovée-Geurts PHM, De Grip WJ, Broekhuyse RM. Rhodopsin-induced experimental autoimmune uveoretinitis: dose dependent clinicopathological features. Exp Eye Res 1988; 47: 135-45.

Accepted for publication 14 April 1988. 